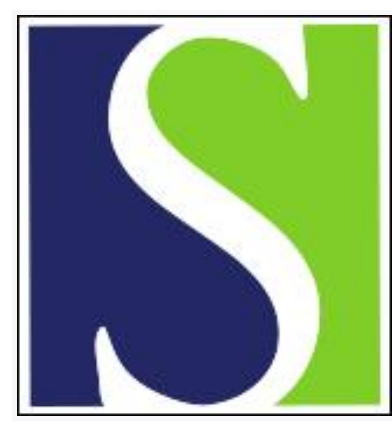

Scand J Work Environ Health 1994;20(6):451-458

https://doi.org/10.5271/sjweh.1375

Issue date: 01 Dec 1994

Urinary mandelic acid and hemoglobin adducts in fiberglass-reinforced plastics workers exposed to styrene.

by Severi M, Pauwels W, Van Hummelen P, Roosels D, Kirsch-Volders $M$, Veulemans $\mathrm{H}$

Affiliation: Laboratory of Occupational Hygiene and Toxicology, Occupational and Insurance Medicine, Katholieke Universiteit Leuven, Belgium.

This article in PubMed: www.ncbi.nlm.nih.gov/pubmed/7701291 


\title{
Urinary mandelic acid and hemoglobin adducts in fiberglass-reinforced plastics workers exposed to styrene
}

\author{
by Mario Severi, MSc, ${ }^{1}$ Wim Pauwels, MSc ${ }^{1}$, Paul Van Hummelen, MSc, ${ }^{2}$ Daniel Roosels, $\mathrm{PhD},{ }^{3}$ \\ Micheline Kirsch-Volders, PhD, ${ }^{2}$ Hendrik Veulemans, $\mathrm{PhD}^{1}$
}

\begin{abstract}
SEVERI M, PAUWELS W, VAN HUMMELEN P, ROOSEIS D, KIRSCH-VOLDERS M, VEULEMANS $H$. Urinary mandelic acid and hemoglobin adducts in fiberglass-reinforced plastics workers exposed to styrene. Scand J Work Environ Health 1994;20:451-8.
\end{abstract}

\begin{abstract}
OBJectives - A field study was undertaken to investigate the effects of occupational styrene exposure on mandelic acid excretion and the formation of styrene-7,8-oxide hemoglobin adducts. Especially the sensitivity of a gas chromatography-mass spectrometry method for determining hemoglobin adducts was evaluated.

METHoDs - Over a four-week period, each individual of a group of 52 fiberglass-reinforced plastics workers was monitored once a week by the simultaneous measurement of styrene in the air and urinary postshift mandelic acid. In addition mandelic acid and hemoglobin adducts were monitored in a group of 24 unexposed referents. At the end of the monitoring period styrene-7,8-oxide adduct formation on $\mathrm{N}$-terminal valine in hemoglobin was examined by gas chromatography-mass spectrometry according to the modified Edman degradation technique.

REsults - Personal air samples showed an average styrene exposure of $31 \mathrm{mg} \cdot \mathrm{m}^{-3}$. The average postshift mandelic acid was $98 \mathrm{mg} \cdot \mathrm{g}$ creatinine ${ }^{-1}$. For workers not wearing respirators and not showing breath ethanol, the correlation coefficient between styrene and mandelic acid was 0.78 . The blood samples were analyzed for styrene-7,8-oxide adducts on hemoglobin. With a detection limit of $10 \mathrm{pmol}$ $\mathrm{g}^{-1}$, no styrene-7,8-oxide adducts were found under these exposure conditions.

Conclusion - Adduct formation in humans is less effective than in mice. In comparison with ethylene, styrene is at least 70 times less effective in forming hemoglobin adducts. Investigating adduct formation in humans at or below the exposure levels reported in this study would require a detection limit of about one order of magnitude better.
\end{abstract}

Key Terms - N-alkylated valine, gas chromatography-mass spectrometry, modified Edman degradation.

As an industrially important chemical, styrene is widely used in the production of plastics and resins. Because of manual application techniques, relatively high exposure occurs in the production of fiberglass-reinforced styrene-polyester resins.

The fate of styrene in humans with respect to uptake is well understood $(1,2)$. The first step in the major metabolic pathway of styrene involves biotransformation to styrene-7,8-oxide via microsomal cytochrome P-450 monooxygenase. The major metabolic excretion products are urinary mandelic acid and phenylglyoxylic acid.

The mutagenic and carcinogenic potency of styrene is activated by the transformation of styrene to

1 Laboratory of Occupational Hygiene and Toxicology, Occupational and Insurance Medicine, Katholieke Universiteit Leuven (Catholic University Louvain), Leuven, Belgium.

2 Laboratory for Antropogenetics, Vrije Universiteit Brussel (Free University Brussels), Brussel, Belgium.

3 Fund of Occupational Diseases, Brussel, Belgium.

Reprints request to: $\mathrm{Dr} \mathrm{H}$ Veulemans, Laboratorium voor Arbeidshygiëne en toxicologie, Kapucijnenvoer 35, 6de verdiep, B-3000 Leuven, Belgium. styrene-7,8-oxide. This epoxide is able to bind covalently to nucleophilic sites in proteins and DNA (deoxyribonucleic acid). The measurement of DNA and hemoglobin adducts is a useful tool for monitoring exposure to electrophilic agents, and it gives some information about their potential mutagenic risk. The determination of DNA adducts is the most suitable parameter for measuring the biologically effective dose of a potential carcinogen. However, the lack of available DNA in tissue samples and the required detection limit makes it very difficult to determine them routinely. In contrast, hemoglobin is sufficiently available in blood samples and has a life span of $120 \mathrm{~d}$. Therefore it is possible to measure a cumulative dose. For determining styrene-7,8-oxide adducts to $\mathrm{N}$-terminal valine in hemoglobin, the $\mathrm{N}$-alkyl Edman degradation technique was used (3).

Styrene-7,8-oxide adduct formation on hemoglobin and DNA following exposure to styrene has been demonstrated in animals $(4,5)$. In humans, styrene7,8-oxide adducts were found in three recent studies. Brenner et al (6) found higher adduct levels in styrene-exposed workers than in unexposed referents. Christakopoulos et al (7) found low but detectable 
styrene-7,8-oxide adducts on hemoglobin in styreneexposed workers. In lamination workers $\mathrm{O}^{6}$-guanine adducts were detected by Vodicka et al (8) at a level over five times the level in the referents.

Because of limited data concerning styrene-7,8oxide adduct formation in humans, a field study was undertaken to monitor simultaneously hemoglobin adducts, mandelic acid excretion, and cytogenetic end points (unpublished results).

\section{Materials and methods}

\section{Chemicals}

Pentafluorophenyl isothiocyanate (PFPITC) was obtained from Fluka (Buchs, Switzerland) and was used without further purification. Styrene- $\mathrm{d}_{8}$ and m-chloroperbenzoic acid were purchased from Janssen, Beerse, Belgium. Hemoglobin (human) was obtained from Sigma (St Louis, Missouri, United States). Formamide (analytical grade) was extracted with pentane before use. All other chemicals and solvents were of analytical grade and used without further purification.

Synthesis of 2-hydroxy-2-phenylethylvaline. Valine $(1 \mathrm{~g})$ was suspended in $0.1 \mathrm{M}$ sodium hydroxide $(5 \mathrm{ml})$, and styrene-7,8-oxide $(2 \mathrm{~g})$ was added. The suspension was stirred for $21 \mathrm{~d}$ at $80^{\circ} \mathrm{C}$, and then the solid was filtered off. The solid was washed several times with methylene chloride, the yield being 2-hydroxy-2-phenylethylvaline (HOStVal) as a white powder. The nuclear magnetic resonance spectrum $\left(\mathrm{D}_{2} \mathrm{O}, \mathrm{K}_{2} \mathrm{CO}_{3}\right)$ and mass spectrum showed that the reaction occurred only through the chiral beta-carbon of styrene-7,8-oxide and not through the alphacarbon that would result in the formation of 2-hydroxy-1-phenylethylvaline.

The deuterated analogue 2-hydroxy-2-phenyl- $\mathrm{d}_{5}-$ ethyl-d $\mathrm{d}_{3}$-valine (HOStVal- $\mathrm{d}_{8}$ ) was prepared in the same way with the use of deuterated styrene- $\mathrm{d}_{8}-7,8$ oxide.

Synthesis of deuterated styrene- $d_{s}-7,8$-oxide. Styrene$\mathrm{d}_{8}-7,8$-oxide was prepared according to the method of Imuta \& Ziffer (9). $m$-Chloroperbenzoic acid $(1.73 \mathrm{~g})$ was added in small portions over $10 \mathrm{~min}$ at $0^{\circ} \mathrm{C}$ to a stirred solution of styrene- $\mathrm{d}_{8}(5 \mathrm{~g})$ in dichloromethane $(100 \mathrm{ml})$ and a phosphate buffer $(100 \mathrm{ml}$, $\mathrm{Na}_{2} \mathrm{HPO}_{4} 0.1 \mathrm{M}, \mathrm{NaH}_{2} \mathrm{PO}_{4} 0.1 \mathrm{M}, \mathrm{pH} 8$ ). The mixture was stirred for $5 \mathrm{~h}$ at room temperature, then cooled to $0^{\circ} \mathrm{C}$, and again $m$-chloroperbenzoic acid $(1.73 \mathrm{~g})$ was added in small portions over $10 \mathrm{~min}$. The mixture was stirred for another $5 \mathrm{~h}$ at room temperature, and then the organic phase was separated and washed with a saturated sodium thiosulfate solution and water and dried with disodium sulfate. The solvent was evaporated under vacuum and styrene$\mathrm{d}_{8}-7,8$-oxide was purified with flash chromatography (silica gel-chloroform).
Preparation of globin alkylated with styrene oxide. Hemoglobin ( $1 \mathrm{~g}$ ) was dissolved in saline $(7 \mathrm{ml})$, styrene-7,8-oxide $(0.7 \mathrm{ml})$ was added, and the mixture was stirred for $60 \mathrm{~h}$ at $37^{\circ} \mathrm{C}$. The alkylated globin [2-hydroxy-2-phenylethylvaline globin (HOStGb)] was then isolated and washed with ethyl acetate and pentane and dried by a gentle stream of air led over the globin. Globin alkylated with styrene- $d_{8}-7,8-$ oxide $\left(\mathrm{HOStGb}-\mathrm{d}_{8}\right.$ ) was prepared in the same way and used as an internal standard. Both the deuterated and nondeuterated globins were used to establish calibration curves.

\section{Determination of styrene oxide adducts}

Isolation of hemoglobin. Immediately after the blood sampling, the red blood cells were separated by centrifugation at 3000 revolutions $/ \mathrm{min}$ for $10 \mathrm{~min}$. The cells were washed three times with isotonic saline and then lysed through the addition of 1 volume of distilled water. Cell membranes and debris were sedimented by centrifugation at 5000 revolutions/min for $1.5 \mathrm{~h}$. The lysed blood samples were then stored at $-20^{\circ} \mathrm{C}$ until further work-up and analysis. Globin was isolated according to Mowrer et al (10). After the addition of $0.05 \mathrm{M}$ hydrochloric acid $(\mathrm{HCl})$ in 2-propanol, the mixture was centrifuged at 3000 revolutions/min for $10 \mathrm{~min}$, a dark red pellet being left. The globin was precipitated from the supernatant by the addition of ethyl acetate. The globin was filtered and washed twice with ethyl acetate and pentane and then dried by a gentle stream of air passing over the globin.

Derivatization. Derivatization of the globin samples was based on the Edman degradation technique (3), in which the $\mathrm{N}$-terminal valine, alkylated by styrene7,8-oxide, specifically is split off as a pentafluorophenyl thiohydantoin (HOStVal PFPTH).

About $50 \mathrm{mg}$ of globin was dissolved in $1.5 \mathrm{ml}$ of formamide and HOStGb- $\mathrm{d}_{8}$, containing $17.3 \mathrm{pmol}$ of $\mathrm{N}$-alkylated valine (HOStVal- $\mathrm{d}_{8}$ ), was added as an internal standard. To adjust the $\mathrm{pH}, 30 \mu \mathrm{l}$ of sodium hydroxide (1 M) was added, followed by $15 \mu$ l of PFPITC. The mixture was shaken overnight at room temperature, and the derivatization was completed at $45^{\circ} \mathrm{C}$ for $90 \mathrm{~min}$. The reaction mixture was extracted three times with ether $(2 \mathrm{ml})$, and the combined extracts were evaporated to dryness under nitrogen. The residue was redissolved in toluene $(1 \mathrm{ml})$ and washed twice with $2 \mathrm{ml}$ of sodium hydrogen carbonate $\left(\mathrm{NaHCO}_{3}\right)(0.1 \mathrm{M})$ and finally with water. After evaporation to dryness, the residue was redissolved in $50 \mu \mathrm{l}$ of toluene for analysis by gas chromatography-mass spectrometry.

Determination by means of gas chromatographymass spectrometry. The analyses were carried out with a HP 5890 series II gas chromatograph coupled 
to a HP 5970 quadruple mass spectrometer and a HP 59940A workstation. The chromatographic separation of the different components in the samples was made on a DB-5-ms fused silica capillary column ( $30 \mathrm{~m} \times 0.32 \mathrm{~mm}, 0.12 \mu \mathrm{m}$ phase thickness). Helium was used as the carrier gas. The samples were injected $(1-10 \mu \mathrm{l})$ by a solid injector. The oven temperature was programmed at $5^{\circ} \mathrm{C}$ per minute from 150 to $250^{\circ} \mathrm{C}$, followed by an increase of $10^{\circ}$ per minute to $300^{\circ} \mathrm{C}$.

The mass spectrometer was operated in the electron impact mode with an electron energy of $70 \mathrm{eV}$. The interface temperature was $270^{\circ} \mathrm{C}$, and the source pressure was $0.005 \mathrm{~Pa}$. The analyses were carried out with selected ion monitoring.

Calibration. Calibration curves were established from mixtures of HOStGb $(0-10 \mu \mathrm{g}$, containing $2.03 \mathrm{nmol}$ HOStVal per milligram of hemoglobin), HOStGb-d $\mathrm{d}_{8}(10 \mu \mathrm{g}$, containing $1.73 \mathrm{nmol}$ of HOStVal-d per milligram of hemoglobin) and $50 \mathrm{mg}$ of unalkylated hemoglobin. The samples were derivatized and analyzed according to the preceding description.

Calibration of reference globin. First, solutions of HOStVal and HOStVal- $\mathrm{d}_{8}$ were prepared in a mixture of 1-propanol and $0.5 \mathrm{M} \mathrm{NaHCO}_{3}$ (volume/volume 1/2). A calibration curve was established with the use of mixtures of HOStVal $(5-500 \mu \mathrm{l}$ of a solution containing $1 \mathrm{nmol} \cdot \mathrm{ml}^{-1}$ ) and HOStVal- $\mathrm{d}_{8}$ ( $50 \mu \mathrm{l}$ of a solution containing $1 \mathrm{nmol} \cdot \mathrm{ml}^{-1}$ ). The mixtures were derivatized as described by Törnqvist et al (3). 1-Propanol/ $\mathrm{NaHCO}_{3}$ was added until the total volume was $1.5 \mathrm{ml}, 15 \mu \mathrm{l}$ of PFPITC was added, and the mixture was stirred at $45^{\circ} \mathrm{C}$ for $90 \mathrm{~min}$. Then the reaction mixture was extracted twice with n-heptane $(2 \mathrm{ml})$, and the combined extracts were evaporated to dryness under nitrogen. The residue was redissolved in toluene $(1 \mathrm{ml})$ and washed twice with $2 \mathrm{ml}$ of $\mathrm{NaHCO}_{3}(0.1 \mathrm{M})$ and finally with water. After evaporation to dryness, the residue was redissolved in $50 \mu \mathrm{l}$ of toluene and analyzed by means of gas chromatography-mass spectrometry.

For the determination of the adduct level in the reference globin, $10 \mathrm{mg}$ of HOStGb was dissolved in $0.5 \mathrm{ml}$ of $6 \mathrm{M} \mathrm{HCl}$, and $0.5 \mathrm{ml}$ of a solution containing 100 pmol HOStVal-d ${ }_{8}$ per milliliter of $\mathrm{HCl}$ $(6 \mathrm{M})$ was added. Then the reaction flask was closed under nitrogen and stirred for $16 \mathrm{~h}$ at $120^{\circ} \mathrm{C}$ to hydrolyze the globin. Aliquots of $20 \mu \mathrm{l}$ of the hydrolysate were evaporated to dryness and redissolved in $1.5 \mathrm{ml}$ of 1 -propanol/ $/ \mathrm{NaHCO}_{3}$. Derivatization and sample preparation were carried out as already described. With the use of the previous calibration curve the adduct level in HOStGb was determined.

The adduct level in HOStGb- $\mathrm{d}_{8}$ was determined in a similar way, HOStVal being used as the internal standard.
Determination of ethylene oxide adducts. The amount of hydroxyethylvaline (HOEtVal) was determined simultaneously with HOStVal using $\mathrm{HOStGb}-\mathrm{d}_{8}$ as an internal standard. Calibration curves were established with mixtures of hemoglobin alkylated with ethylene oxide ( $0-30 \mathrm{pmol}$ of HOEtVal), HOStGb$\mathrm{d}_{8}\left(10 \mu \mathrm{g}\right.$, containing $1.73 \mathrm{nmol}$ HOStVal- $\mathrm{d}_{8} \cdot \mathrm{mg}$ hemoglobin ${ }^{-1}$ ) and $50 \mathrm{mg}$ of unalkylated hemoglobin. The hemoglobin alkylated with ethylene oxide was a gift from NJ Van Sittert (Shell, The Netherlands).

\section{Analysis of air and urine samples}

The air samples collected in a charcoal tube were analyzed on a HP 5880 A gas chromatograph equipped with a dual wall-coated open tubular (WCOT) capillary column system (Carbowax 20M, $50 \mathrm{~m} \times 0.2 \mathrm{~mm}$, phase thickness $0.2 \mu \mathrm{m}$ and $\mathrm{OV}-1$, $50 \mathrm{~m} \times 0.2 \mathrm{~mm}$, phase thickness $0.2 \mu \mathrm{m}$ ), dual flame ionization detector and an automatic injector $(0.1 \mu \mathrm{l})$ with an inlet splitter (ratio 1:10). Helium was used as the carrier gas. All samples were analyzed simultaneously on both columns. The oven temperature was programmed at $40^{\circ} \mathrm{C}$ for $10 \mathrm{~min}$ followed by an increase of $10^{\circ}$ per minute from 40 to $200^{\circ} \mathrm{C}$. Sample preparation was done by chemical desorption with $1 \mathrm{ml}$ of carbon disulfide. Calibration curves were established by spiking charcoal tubes with different amounts of styrene.

The air samples collected with organic vapor monitors were analyzed on an HP 5890 series II gas chromatograph equipped with a WCOT capillary column (CP-Sil $5,50 \mathrm{~m} \times 0.32 \mathrm{~mm}$, phase thickness $0.12 \mu \mathrm{m}$ ), flame ionization detector and an automatic injector $(1 \mu \mathrm{l})$ with an inlet splitter (ratio 1:50). Helium was used as the carrier gas. The oven temperature increase was programmed at $5^{\circ}$ per minute from 45 to $95^{\circ} \mathrm{C}$. Sample preparation was done by chemical desorption with $1.5 \mathrm{ml}$ of carbon disulfide. Calibration curves were obtained by spiking the monitors with known amounts of styrene.

Mandelic acid in urine was determined by high pressure-liquid chromatography. The analysis was performed on a Varian model 5000 high pressureliquid chromatograph equipped with a $\mathrm{C}$ - 18 reverse phase column (ET 250/8/4 Nucleosil 120-7 $\mathrm{C}_{18}, 250$ $\mathrm{mm} \times 4 \mathrm{~mm}$, particle size $7 \mu \mathrm{m}$ ), automatic injector $(20 \mu \mathrm{l})$, ultraviolet detector $(220 \mathrm{~nm})$ and an electronic integrator. A mixture of $80 \%$ water, containing $0.5 \%$ acetic acid (pH 4.6) and 20\% methanol, was used as the eluent. Sample preparation was done through the extraction of mandelic acid with ethyl acetate, evaporation of the extract, and the redissolving of the dried extract in water. All of the mandelic acid values have been expressed in milligrams per gram of creatinine. Different concentrations of mandelic acid in water were analyzed to establish a calibration curve. 4-Hydroxy-benzoic acid was used as an internal standard. 


\section{Sampling procedure}

In the exposed group, air and urine samples were taken once a week during four consecutive weeks. Air samples were collected on 3M 3500 organic vapor monitors and on standard charcoal tubes (100/ $50 \mathrm{mg}$, SKC Inc, United States, lot 120) with the aid of accuhaler pumps from MDA Scientific Inc, United States (type $808,50 \mathrm{ml} \cdot \mathrm{min}^{-1}$ ). Considering the type of work, it was judged that half-shift air samples would be representative for the entire workday. Urine samples were collected on the same day as the air samples at the end of the shift. At the end of the monitoring period, blood samples were collected in heparinized Vacutainer ${ }^{\circledR}$ tubes for the analysis of hemoglobin adducts and in Vacutainer ${ }^{\circledR}$ tubes containing calparine for the determination of cytogenetic end points.

\section{Subjects and worksites}

A group of 52 men (ages $21-52$ years) daily exposed to styrene participated in the study. These workers were employed in a plant manufacturing fiberglass-reinforced plastic pipes and cisterns. As this study was incorporated into the health policy of the factory, all workers of the fiberglass-reinforced styrene-polyester resin plant participated in the study. The plant was divided into the following three units: pipe production (unit I), pipe finishing (unit II), cistern production and finishing (unit III). Work was organized into three shifts in unit I and into a single day shift in units II and III. The main activity in unit I consisted of operating the feeders for the production of pipes (14 workers), laminating standard connectors for the pipes (11 workers), and cutting and transporting the pipes (8 workers). In unit II the main activity consisted of laminating special connectors for the pipes ( 9 workers), preparing different pieces for the connectors ( 2 workers), and transporting the pieces ( 1 worker). Laminating the body of cisterns ( 5 workers) and spraying the end caps for the cisterns ( 2 workers) were the main activities in unit III.

A group of 24 workers from another factory and with a comparable socioeconomic background was

Table 1. Summary of the questionnaire data.

\begin{tabular}{|c|c|c|c|c|c|c|}
\hline & \multicolumn{3}{|c|}{$\begin{array}{l}\text { Exposed group } \\
\qquad(\mathrm{N}=52)\end{array}$} & \multicolumn{3}{|c|}{$\begin{array}{l}\text { Unexposed group } \\
(\mathrm{N}=24)\end{array}$} \\
\hline & Mean & SD & $\%$ & Mean & SD & $\%$ \\
\hline Age (years) & 30.6 & 7.4 & · & 27.2 & 4.5 & . \\
\hline Height $(\mathrm{cm})$ & 177.2 & 6.2 & $\cdot$ & 176.4 & 5.6 & . \\
\hline Weight (kg) & 77.8 & 11.3 & . & 71.3 & 12.0 & . \\
\hline Education (years) & 8.8 & 2.1 & . & 9.8 & 1.0 & $\cdot$ \\
\hline \multicolumn{7}{|l|}{ Smoking } \\
\hline $\begin{array}{l}\text { Nonsmokers } \\
\text { Smokers } \\
\text { Cigarettes per day } \\
\text { Ex-smokers }\end{array}$ & & 8 & $\begin{array}{r}35 \\
52 \\
. \\
13\end{array}$ & 18 & : & $\begin{array}{r}46 \\
50 \\
\cdot \\
4\end{array}$ \\
\hline Coffee (cups/day) & 3.6 & 4.0 & . & 4.8 & 3.7 & . \\
\hline Alcohol (drinks/day) & 1.0 & 1.5 & $\cdot$ & 2.6 & 2.7 & . \\
\hline$X$ rays (years ago) & 0.6 & 0.2 & . & 3.6 & 1.9 & . \\
\hline
\end{tabular}

monitored as a reference group. These workers were employed in the production and repair of wooden pallets and were not exposed to styrene or organic solvents. Mandelic acid was not detected in their urine samples.

\section{Questionnaire}

At the end of the monitoring period the subjects were asked to answer a questionnaire. In the questionnaire, information was recorded about such items as number of years worked in current occupation, past employment, specific description of task, and use of protective equipment. Other points of interest were life-style factors (drinking, eating, smoking) and medical history (X rays, history of cancer).

An overview of the data collected with the questionnaire is presented in table 1 . The general features of the exposed and reference groups were similar. The admitted alcohol intake was higher in the reference group. Because of the use of asbestos in other units of the factory, radiography is part of the yearly medical check-up. This policy explains the difference between the exposed subjects and the referents in years since the last $X$ ray was taken. Smaller differences were found for age, weight, and years of education.

The mean time in the current job was 0.9 (range $0.1-5.2$ ) years. In units I and II, the time worked in the unit was always less than one year. In unit III the mean time was 3.0 years. Thirty of the 52 subjects had worked earlier with asbestos, mostly in the asbestos cement unit of the same plant.

\section{Statistical methods}

The distribution of the exposure data on styrene and mandelic acid differed significantly from the normal distribution. A log-transformation of the data yielded a better approximation of the normal distribution. Both arithmetic and geometric means were calculated. All parameters of the different exposure groups were compared by means of a two-way analysis of variance.

A simple and multiple regression was used to study the relation between the exposure to styrene and the level of mandelic acid found in the urine samples. Because of the departures from normality a Spearmann rank correlation was also calculated.

The statistical analysis was performed with SAS (statistical analysis system) using SAS/ASSIST software, version 6 , first edition.

\section{Results}

\section{Analysis of the air and urine samples of the} exposed workers

The analysis of the personal air samples for styrene showed an exposure range of $2.2-110.1 \mathrm{mg} \cdot \mathrm{m}^{-3}$ and a mean of $31.0 \mathrm{mg} \cdot \mathrm{m}^{-3}\left(\right.$ mean $_{\text {geom }}=22.4 \mathrm{mg}$. 
$\mathrm{m}^{-3}$ ). Exposure to styrene was significantly higher $(\mathrm{P}<0.001)$ in unit I. In units II and III the exposure levels were similar (table 2). Other products found in the air samples were mainly acetone and methyl ethyl ketone. In some of the air samples ethanol was detected in a range of $0.3-55 \mathrm{mg} \cdot \mathrm{m}^{-3}$, indicating recent alcohol consumption by the subjects.

Mandelic acid in the urine samples was found in the range of $11-649 \mathrm{mg} \cdot \mathrm{g}$ creatinine $^{-1}$ and a mean of $102 \mathrm{mg} \cdot \mathrm{g}_{\text {creatinine }}{ }^{-1}\left(\mathrm{mean}_{\mathrm{geom}}=76 \mathrm{mg} \cdot \mathrm{g}\right.$ creatinine $\left.{ }^{-1}\right)$. The level of mandelic acid in urine was significantly higher $(P<0.001)$ in unit I. No significant difference was found between units II and III (table 2).

The relation between styrene exposure and mandelic acid was studied by multiple linear regression analysis for subjects not wearing respirators, the presence of ethanol in the breathing zone being used as a dummy variable. The highly significant interaction between the presence of ethanol and styrene expo- sure $(\mathrm{P}<0.0001)$ indicated different slopes for the regression lines.

For persons not having breath ethanol, the best fitting regression model without intercept was $(\mathrm{r}=$ $0.78)$ mandelic acid $\left(\mathrm{mg} \cdot \mathrm{g}\right.$ creatinine $\left.{ }^{-1}\right)=3.52$ styrene $\left(\mathrm{mg} \cdot \mathrm{m}^{-3}\right)$ (Spearmann's $\left.\mathrm{r}=0.76\right)$. The 95\% confidence interval was between 3.15 and 3.96 (figure 1).

For persons with breath ethanol, the best fitting regression model without intercept was $(r=0.48)$ mandelic acid $\left(\mathrm{mg} \cdot \mathrm{g}\right.$ creatinine $\left.{ }^{-1}\right)=2.38$ styrene $\left(\mathrm{mg} \cdot \mathrm{m}^{-3}\right)($ Spearmann's $\mathrm{r}=0.56)$. The $95 \%$ confidence interval was between 1.87 and 2.90 .

\section{Optimization of the gas chromatography-mass spectrometry procedure}

In vitro styrene-7,8-oxide adduct formation on the $\mathrm{N}$-terminal valine in hemoglobin mainly occurs through the chiral beta-carbon of styrene-7,8-oxide,

Table 2. Styrene exposure and urinary mandelic acid levels of the exposed workers in the different units.

\begin{tabular}{|c|c|c|c|c|c|c|c|c|}
\hline \multirow{2}{*}{ Unita } & \multicolumn{5}{|c|}{ Styrene in air $\left(\mathrm{mg} \cdot \mathrm{m}^{-3}\right)$} & \multicolumn{3}{|c|}{$\begin{array}{l}\text { Mandelic acid in urine } \\
\left(\mathrm{mg} \cdot \mathrm{g} \text { creatinine }^{-2}\right)\end{array}$} \\
\hline & $\begin{array}{l}\text { Arithmetic } \\
\text { mean }\end{array}$ & $S D^{b}$ & $\begin{array}{l}\text { Geometric } \\
\text { mean }\end{array}$ & $S D^{c}$ & Exposure range & $\begin{array}{l}\text { Arithmetic } \\
\text { mean }\end{array}$ & $\mathrm{SD}$ & Range \\
\hline $\begin{array}{l}\text { I }(N=33) \\
\text { II }(N=12) \\
\text { III }(N=7)\end{array}$ & $\begin{array}{l}41.3 \\
12.0 \\
13.3\end{array}$ & $\begin{array}{r}21.5 \\
2.6 \\
6.5\end{array}$ & $\begin{array}{r}36.6 \\
8.3 \\
11.6\end{array}$ & $\begin{array}{l}1.7 \\
2.5 \\
1.7\end{array}$ & $\begin{array}{c}12.9-110.1 \\
2.2-25.4 \\
4.3-20.6\end{array}$ & $\begin{array}{r}135 \\
48 \\
37\end{array}$ & $\begin{array}{r}110 \\
28 \\
13\end{array}$ & $\begin{array}{l}50-649 \\
11-114 \\
14-58\end{array}$ \\
\hline Total $(\mathrm{N}=52)$ & 31.0 & 22.4 & 22.4 & 2.5 & $2.2-110.1$ & 102 & 99 & $11-649$ \\
\hline
\end{tabular}

a Number of workers in parentheses.

b Standard deviation of the arithmetic mean.

c Standard deviation of the geometric mean.

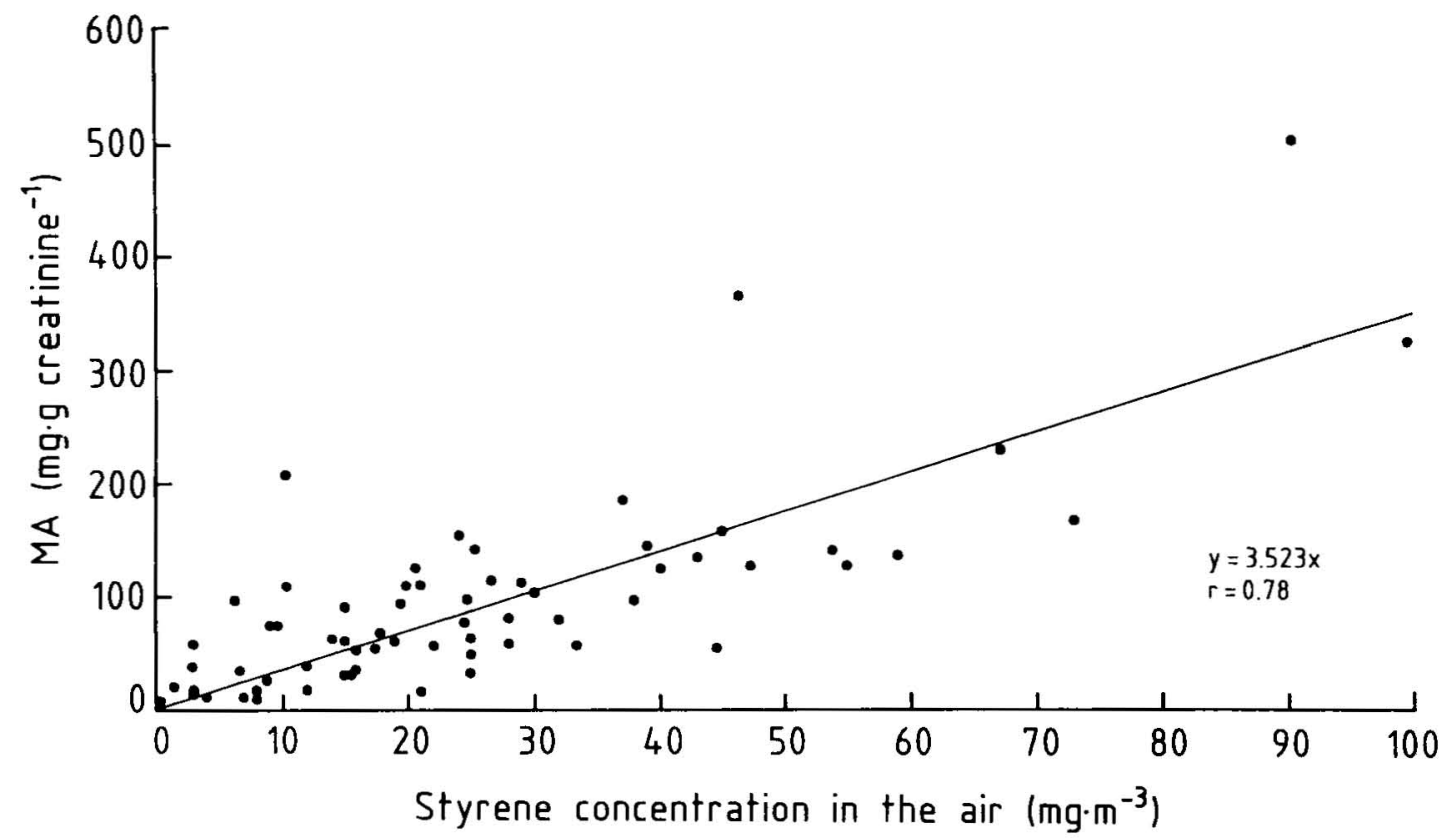

Figure 1. Regression between the exposure to styrene and the level of mandelic acid (MA) found in the urine samples of persons not wearing respirators and not having breath ethanol $(\mathrm{N}=92)$. 
resulting in the formation of two diastereoisomers of the valine adduct (7). After derivatization of the adduct, both isomers were separated by means of gas chromatography on a DB-5-ms capillary column. The mass spectrum of HOStVal PFPTH is shown in figure 2; it was identical for both isomers. The base peak, 325, corresponds with a loss of $\left(\mathrm{C}_{6} \mathrm{H}_{5}\right) \mathrm{CHOCH}$. Besides the proton shift attending the McLafferty rearrangement, the fragmentation was accompanied by a second proton shift from the nearby carbon towards the positively charged nitrogen (figure 2 ). In the case of the deuterated internal standard, a deuterium shift replaced this second proton shift and resulted in the formation of a fragment with $326 \mathrm{amu}$. Because of their high abundance (sensitivity) and high mass number (selectivity), these ions were used for the selected ion monitoring analysis. The internal standard eluted a few seconds before the deriva-

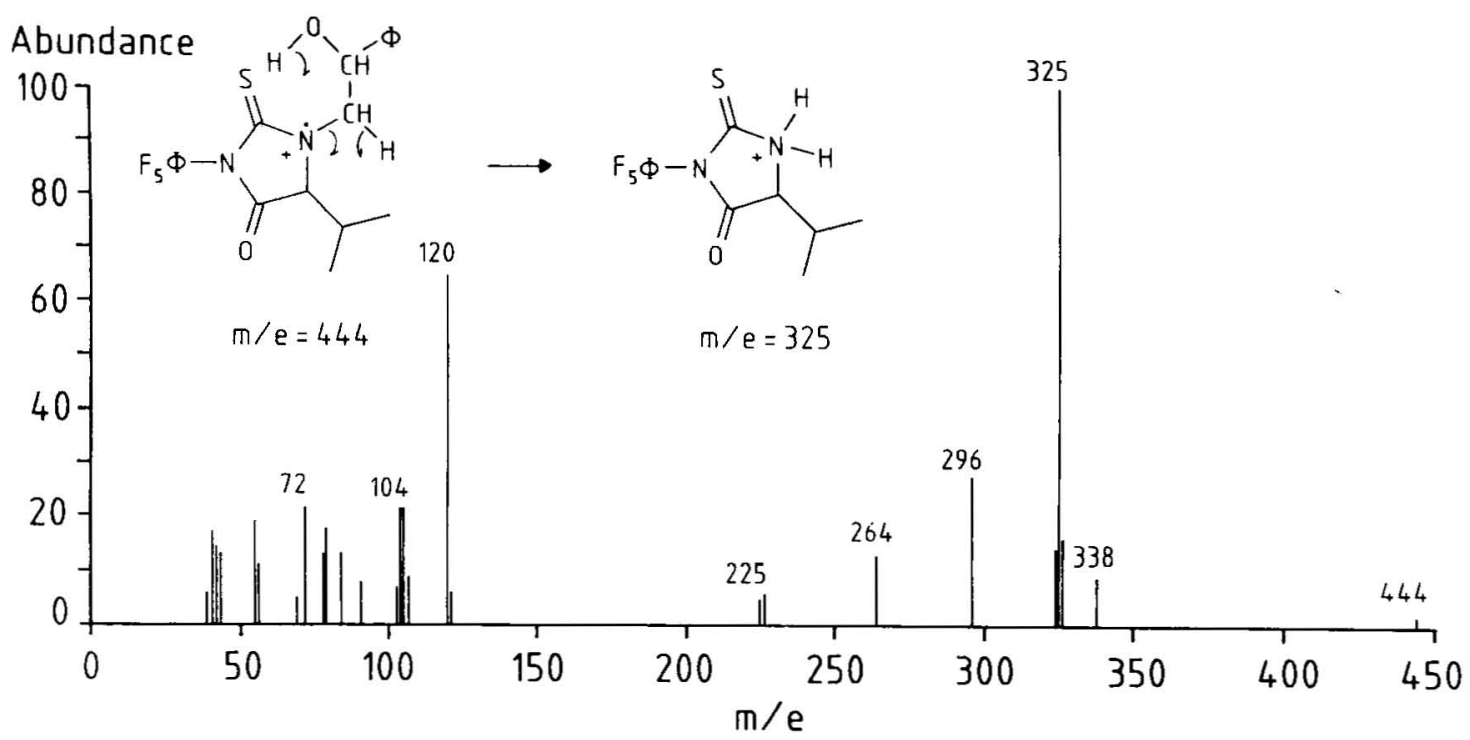

Figure 2. Mass spectrum (EI) of the pentafluorophenyl thiohydantoin derivative of 2-hydroxy-2-phenylethylvaline. The base peak, 325, corresponds to a loss of $\left(\mathrm{C}_{6} \mathrm{H}_{5}\right) \mathrm{CHOCH}$. Besides the proton shift attending the McLafferty rearrangement, the fragmentation is accompanied by a second proton shift from the nearby carbon towards the positively charged nitrogen.
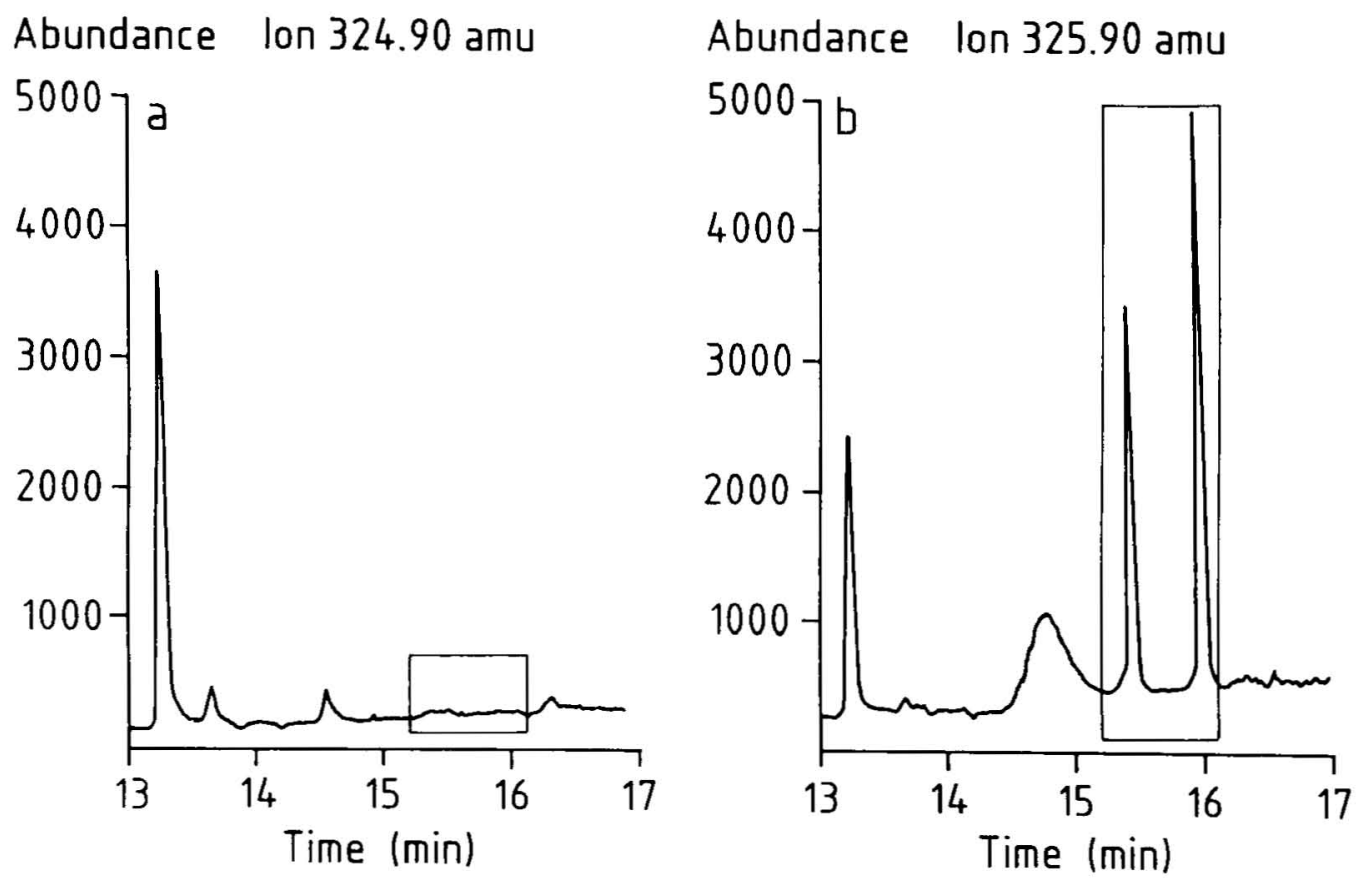

Figure 3. Chromatogram of typical selected ions of the pentafluorophenyl thiohydantoin derivative of 2-hydroxy-2-phenylethylvaline from a styrene-exposed worker. Both isomers of the internal standard are clearly detectable in chromatogram $b$, but no styrene oxide adducts are present in chromatogram a. 
tized adduct. The parameters of the mass spectrometer were adjusted to allow simultaneous detection of both styrene-7,8-oxide and ethylene oxide adducts in hemoglobin. The fragment with 308 amu corresponding with the loss of $\mathrm{NHCH}_{2} \mathrm{CH}_{2} \mathrm{OH}$, was monitored for the ethylene oxide adducts. With these adjustments, a detection limit of $10 \mathrm{pmol} \cdot \mathrm{g}^{-1}$ was reached.

\section{Analysis of the blood samples}

The blood samples were analyzed for styrene-7,8oxide adducts on the N-terminal valine in hemoglobin. A typical result is shown in figure 3. In none of the blood samples were styrene-7,8-oxide adducts detected. In contrast, ethylene oxide adducts were clearly present in all of the samples. Although the difference was statistically not significant, the smokers showed higher ethylene oxide adduct levels than the nonsmokers. The adduct levels in smokers were found in a range of $35-314 \mathrm{pmol} \cdot \mathrm{g}^{-1}$ with a mean of $130 \mathrm{pmol} \cdot \mathrm{g}^{-1}\left(\right.$ mean $\left._{\mathrm{geom}}=110 \mathrm{pmol} \cdot \mathrm{g}^{-1}\right)$, while the level in nonsmokers showed a range of 27$175 \mathrm{pmol} \cdot \mathrm{g}^{-1}$ and a mean of $97 \mathrm{pmol} \cdot \mathrm{g}^{-1}\left(\right.$ mean $_{\text {geom }}$ $\left.=85 \mathrm{pmol} \cdot \mathrm{g}^{-1}\right)$.

\section{Discussion}

The styrene exposure was monitored by half-shift air samples. For the evaluation of these data as a measure for the average daily exposure, the styrene concentration in the air samples was compared with mandelic acid in the end-shift urine samples. Only data from individuals not wearing respirators during the sampling period were taken into account (11). Since there was no ethanol used in the production process, the presence of ethanol in the breathing zone (air samples) indicated the intake of a substantial amount of alcohol by some workers before work or during the breaks. Wilson et al (12) and Berode et al (13) reported the kinetics of mandelic acid excretion to be substantially altered in human volunteers exposed to both styrene and ethanol. Also in this study, a highly significant interaction was found between alcohol intake before or during work and styrene exposure, a finding indicating that alcohol intake significantly delays mandelic acid excretion. Therefore the relation between styrene exposure and urinary mandelic acid was calculated for subjects not showing breath ethanol. The good correlation between both parameters in this subgroup supports the assumption that half-shift air samples were representative for the average daily exposure. The $95 \%$ confidence interval calculated for the level of mandelic acid in urine corresponding with a styrene exposure of $213 \mathrm{mg} \cdot \mathrm{m}^{-3}$ (occupational exposure limit) was between 671 and $843 \mathrm{mg} \cdot \mathrm{g}$ creatinine ${ }^{-1}$. This interval is consistent with the present biological exposure index of $800 \mathrm{mg} \cdot \mathrm{g}$ creatinine ${ }^{-1}$ of the American Conference of Governmental Industrial Hygienists.
Styrene-7,8-oxide adducts were not found in any of the exposed workers. This result implies that the level of adduct formation in the highest exposed subgroup (unit I, $41.3 \mathrm{mg} \cdot \mathrm{m}^{-3}$ ) could have been at most $10 \mathrm{pmol} \cdot \mathrm{g}$ hemoglobin ${ }^{-1}$, the detection limit of our method. In comparison, exposure to $1 \mathrm{ppm}$ of ethene gives approximately 70 pmol hydroxyethylvaline (adduct of ethylene) $\cdot \mathrm{g}$ hemoglobin ${ }^{-1}(14)$. Therefore styrene is at least 70 times less effective in comparison with ethylene with respect to adduct formation to hemoglobin.

A field study on mice by Byfält Nordqvist et al (4) indicated that the intraperitoneal injection of $1.1 \mathrm{mmol}$ styrene $\cdot \mathrm{kg}$ body weight ${ }^{-1}$ leads to the formation of $3 \mathrm{nmol}$ alkylated $\mathrm{N}$-terminal valine $\mathrm{g}$ hemoglobin ${ }^{-1}$. Extrapolation of these results to humans would mean that adducts would still be detectable at the exposure levels of our study. The fact that no adducts were found possibly reflects an important species difference in styrene metabolism. Styrene is primarily eliminated by metabolism, and the initial and rate-limiting step in the metabolism of styrene is catalyzed by microsomal monooxygenase. The epoxide is detoxified by epoxide hydrolase. Mendrala et al (15) reported that the activity of the epoxide hydrolase relative to monooxygenase activity was much greater in human liver than in mouse liver. The apparent half-time for styrene-7,8-oxide in mouse and human was calculated to be 38 and $1.8 \mathrm{~min}$, respectively.

Only a few studies report the presence of styrene7,8 -oxide adducts on hemoglobin in humans. Brenner et al (6) found a higher adduct level in styreneexposed workers $\left(\mathrm{mean}_{\text {geom }}=48.2 \mathrm{mg} \cdot \mathrm{m}^{-3}\right)$ versus referents. The difference between both groups was not statistically significant and mainly due to one individual with a high adduct level. Farmer et al (16) have studied occupational exposure to styrene with a limited number of samples, but no adducts have so far been detected. Recently Christakopoulos et al (7) found styrene-7,8-oxide adducts on hemoglobin (mean $28 \mathrm{pmol} \cdot \mathrm{g}^{-1}$ ) in styrene-exposed workers (mean $= \pm 300 \mathrm{mg} \cdot \mathrm{m}^{-3}$ ). This finding is not inconsistent with our results. The mean exposure in that study was about seven times higher than that of our most exposed subgroup (unit I). Extrapolating the adduct levels found by Christakopoulos et al (7) to the exposure level of our subgroup I would result in an expected adduct level of about $4 \mathrm{pmol} \cdot \mathrm{g}^{-1}$. This value is clearly below the detection limit of the present method. To study adduct formation in humans at or below exposure concentrations of $40 \mathrm{mg}$. $\mathrm{m}^{-3}$ would require a detection limit which is about one order of magnitude better.

In the study of Vodicka et al (8) DNA adducts were found at exposure levels comparable with the levels reported in the study of Christakopoulos et al (7). The small differences in adduct levels between the exposed persons ( 5 adducts per $10^{8}$ nucleotides) and the referents ( 1 adduct per $10^{8}$ nucleotides) in- 
dicate that, with the present techniques, DNA adducts are not more sensitive biomarkers for monitoring exposure to styrene at the low levels reported in this study.

Several studies report a significantly higher level of ethylene oxide adducts on hemoglobin in cigarette smokers than in nonsmokers $(17-20)$. The absence of a significant difference in ethylene oxide adducts between smokers and nonsmokers is probably due to the safety policy of the factory. Since smoking was not allowed in the work area, the number of cigarettes smoked was rather low $(50 \%$ of the smokers smoked 15 or fewer cigarettes per day).

\section{Acknowledgments}

We wish to thank Dr J Rombouts and Mr F Beullens for their cooperation in the fiberglass-reinforced styrene-polyester resin plant. We also would like to thank Dr J Van Cleemput for providing us with control samples.

This research was supported by the Belgian Incentive Program Health Hazards initiated by the Belgian Science Policy Office.

\section{References}

1. Guillemin MP, Bauer D. Human exposure to styrene: III. elimination kinetics of urinary mandelic and phenylglyoxylic acids after single experimental exposure. Int Arch Occup Environ Health 1979;44:249-63.

2. Wigaeus E, Löf $A$, Bjurström R, Byfält Nordqvist M. Exposure to styrene: uptake, distribution, metabolism and elimination in man. Scand J Work Environ Health 1983;9:479-88.

3. Törnqvist M, Mowrer J, Jensen S, Ehrenberg L. Monitoring of environmental cancer initiators through hemoglobin adducts by a modified Edman degradation method. Anal Biochem 1986;154:255-6.

4. Byfält Nordqvist $M$, Löf $A$, Osterman-Golkar $S$, Walles SAS. Covalent binding of styrene and styrene7,8-oxide to plasma proteins, hemoglobin and DNA in the mouse. Chem Biol Interact 1985;55:63-73.

5. Cantoreggi S, Lutz WK. Covalent binding of styrene to DNA in rat and mouse. Carcinogenesis 1993;14(3): $355-60$.

6. Brenner DD, Jeffrey AM, Latriano L, Wazneh L, Warburton $\mathrm{D}$, Toor $\mathrm{M}$, et al. Biomarkers in styrene-exposed boatbuilders. Mutat Res 1991;261:225-36.

7. Christakopoulos A, Bergmark E, Zorcec V, Norppa H, Mäki-Paakkanen J, Osterman-Golkar S. Monitoring occupational exposure to styrene from hemoglobin adducts and metabolites in blood. Scand J Work En- viron Health 1993;19:255-63.

8. Vodicka P, Vodickova L, Hemminki K. 32P-postlabeling of DNA adducts of styrene-exposed lamination workers. Carcinogenesis 1993;14(10):2059-61.

9. Imuta M, Ziffer H. Convenient method for the preparation of reactive oxiranes by direct epoxidation. J Org Chem 1979;44(8): 1351-2.

10. Mowrer J, Törnqvist M, Jensen S, Ehrenberg L. Modified Edman degradation applied to hemoglobin for monitoring occupational exposure to alkylating agents. Toxicol Environ Chem 1986;11:215-31

11. Löf A, Brohede C, Gullstrand E, Lindström K, Sollenberg J, Wrangskog $\mathrm{K}$, et al. The effectiveness of respirators measured during styrene exposure in a plastic boat factory. Int Arch Occup Environ Health 1993; $65: 29-34$.

12. Wilson HK, Robertson SM, Waldron HA, Gompertz D. Effect of alcohol on the kinetics of mandelic acid excretion in volunteers exposed to styrene vapor. $\mathrm{Br}$ J Ind Med 1983;40:75-80.

13. Berode M, Boillat MA, Droz PO, Guillemin M. Effect of alcohol on the kinetics of styrene and its metabolites in volunteers and workers. Appl Ind Hyg 1986;1:25-8.

14. Törnqvist MA, Almberg JG, Bergmark EN, Nilsson $\mathrm{S}$, Osterman-Golkar SM. Ethylene oxide doses in ethene-exposed fruit store workers. Scand J Work Environ Health $1989 ; 15: 436-38$.

15. Mendrala AL, Langvardt PW, Nitschke KD, Quast JF, Nolan RJ. In vitro kinetics of styrene and styrene oxide metabolism in rat, mouse, and human. Arch Toxicol 1993;67:18-27

16. Farmer PB, Tang Y-S, Anderson D, Sepai O, Bailey E. Biomonitoring exposure to styrene oxide by GCMS analysis of its adducts with hemoglobin. Washington, DC: Styrene Information and Research Center, 1993. The SIRC review: special report (The $\mathrm{Hel}-$ sinki symposium on butadiene and styrene), vol 3, no $1: 42$.

17. Passingham BJ, Farmer PB, Bailey E, Brooks AGF, Yates DW. 2-Hydroxyethylation of hemoglobin in man. Lyon: International Agency for Research on Cancer (IARC), 1988:279-84. IARC scientific publications, no 89 .

18. Persson K-A, Berg S, Törnqvist M, Scalia-Tomba GP, Ehrenberg L. Note on ethene and other low-molecular weight hydrocarbons in environmental tobacco smoke. Acta Chem Scand 1988;42:690-6.

19. Sarto F, Törnqvist M $\AA$, Tomanin R, Bartolucci GB, Osterman-Golkar SM, Ehrenberg L. Studies of biological and chemical monitoring of low-level exposure to ethylene oxide. Scand J Work Environ Health 1991;17: $60-4$.

20. Törnqvist $\mathrm{M}$, Osterman-Golkar S, Kautiainen A, Jensen S, Farmer PB, Ehrenberg L. Tissue doses of ethylene oxide in cigarette smokers determined from adduct levels in hemoglobin. Carcinogenesis 1986;7: $1519-21$.

Received for publication: 17 December 1993 